\title{
Hyperbaric Oxygen Therapy May Have a Favorable Affect on Skin Thickness in Systemic Sclerosis: Experience with Four Patients
}

\author{
D Mehmet Engin Tezcan, ${ }^{1}$ (1) Selin Gamze Sümen²
}

\author{
'Department of Rheumatology, \\ Kartal Dr. Lütfi Kırdar City Hospital, \\ İstanbul, Turkey \\ ${ }^{2}$ Kartal Dr. Lütfi Kırdar City Hospital, \\ Department of Underwater \\ and Hyperbaric Medicine, \\ İstanbul, Turkey \\ Submitted: 15.12 .2020 \\ Accepted: 08.02.2021 \\ Correspondence: \\ Mehmet Engin Tezcan, \\ Kartal Dr. Lütfi Kırdar Şehir Hastanesi, \\ Romatoloji Bölümü, İstanbul, Turkey \\ E-mail: engintez@yahoo.com

\footnotetext{
Keywords: Disease-related disability, hyperbaric oxygen therapy, quality of life, skin thickness, systemic sclerosis.
} \\ Attribution-NonCommercial 4.0 International License.
}

\begin{abstract}
Objective: Hyperbaric oxygen $\left(\mathrm{HBO}_{2}\right)$ therapy has well-known anti-inflammatory and antifibrotic effects. It may be an option for the treatment of chronic wounds including digital ulcers related with systemic sclerosis (SS). The therapy may also have an impact on the fibrotic complications of SS, including skin thickness. The aim of the study was evaluating the effect of $\mathrm{HBO}_{2}$ on skin thickness in SS patients with medical therapy resistant digital ulcers.
\end{abstract}

Methods: This was an observational study. Twenty-five of 68 patients in our SS cohort had digital ulcers. Four of those had medical therapy resistant digital ulcers. First, we administered at least three of the drugs: Calcium channel blockers, acetylsalicylic acid, iloprost and bosentan as combination therapy. Then, unresponsive patients were evaluated together by rheumatologist and underwater and hyperbaric medicine physician for $\mathrm{HBO}_{2}$ indication. Finally, we applied $\mathrm{HBO}_{2}$ to eligible patients for their refractory and active digital ulcers. We evaluated the pre- and post-therapy values of modified Rodnan skin score (mRSS) for skin thickness, health assessment questionnaire for disease-related disability, short-form 36 test for quality of life, and visual analog scores related to skin thickness.

Results: mRSSs of all patients improved after the therapy. Nevertheless, we observed that only one patient's digital ulcers got better with the therapy. Furthermore, disease-related disability and quality of life indices were not improved consistently according to the favorable changes in skin scores.

Conclusion: $\mathrm{HBO}_{2}$ may have a positive effect on skin thickness due to its anti-inflammatory and antifibrotic effects. Disease-related disability and quality of life parameters may improve further with addressing all aspects of the disease.

\section{INTRODUCTION}

Hyperbaric oxygen $\left(\mathrm{HBO}_{2}\right)$ therapy is used to treat several acute and chronic conditions by administering $100 \%$ oxygen at partial pressures higher than the usual barometric pressure at sea level of $760 \mathrm{mmHg}{ }^{\left[{ }^{[l]}\right.}$ Gas embolism, carbon monoxide poisoning, clostridial myositis and myonecrosis, compartment syndrome, decompression sickness, necrotizing soft-tissue infection, refractory osteomyelitis, delayed radiation injury, compromised grafts and flaps, and acute thermal burn injury were approved indications for $\mathrm{HBO}_{2} \cdot{ }^{[2]}$ Moreover, $\mathrm{HBO}_{2}$ is a treatment option for chronic wounds. The beneficial effect of $\mathrm{HBO}_{2}$ on diabetic foot ulcers, arterial insufficiency related wounds, or acute traumatic ischemia was proven by randomized controlled trial. [2] However, there have been no randomized controlled trials that demonstrated the favorable effect of $\mathrm{HBO}_{2}$ on other chronic wounds including digital ulcers in systemic sclerosis (SS). Nevertheless, the beneficial effect of $\mathrm{HBO}_{2}$ on SS-related digital ulcers was shown in two different case series. ${ }^{[3,4]} \mathrm{HBO}_{2}$ may have anti-inflammatory and antiapoptotic effects. During ischemia-reperfusion injury, lipid peroxidation damages endothelium and active neutrophils. [5] $\mathrm{HBO}_{2}$ may limit lipid peroxidation with increasing antioxidant enzymes and controls activation of neutrophils. ${ }^{[6]}$ Furthermore, these effects prevent apoptosis of the endothelium in ischemia-reperfusion injury. ${ }^{[7]}$ Moreover, $\mathrm{HBO}_{2}$ was shown to decrease the level of pro-inflammatory cytokines such as tumor necrosis factor-alpha (TNF- $\alpha$ ), interleukin (IL)-I, IL-6, and interferon-gamma. ${ }^{[8]}$ Inversely, it may increase the levels of anti-inflammatory cytokines such as IL-10. ${ }^{[9]}$ The effect of $\mathrm{HBO}_{2}$ on multiple sclerosis (MS) as an autoimmune disease was evaluated in several studies. ${ }^{\left[{ }^{[0]}\right.}$ However, these studies did not prove the 
beneficial effect of $\mathrm{HBO}_{2}$ on MS. Furthermore, $\mathrm{HBO}_{2}$ may have beneficial effects in refractory inflammatory bowel diseases with lowering the levels of inflammatory cytokines. ${ }^{[1]} \mathrm{HBO}_{2}$ has antifibrotic effects through reduction of hypoxia-related fibrosis, ${ }^{[12]}$ inhibition of pro-inflammatory cytokines, ${ }^{[8]}$ downregulation of transforming growth factor-beta (TGF- $\beta$ ), and interferon-alpha, ${ }^{[13]}$ promoting the apoptosis of fibroblasts, and inhibiting fibroblast activations. ${ }^{[14]}$

Inflammatory, vascular, and mesenchymal mechanisms have roles in the pathogenesis of SS. ${ }^{[15]} \mathrm{HBO}_{2}$ may have a beneficial effect on all of these three mechanisms based on its anti-inflammatory and antifibrotic actions. Therefore, $\mathrm{HBO}_{2}$ may be a promising treatment option for SS-related wounds and fibrotic complications such as increased skin thickness.

In this study, we evaluated the effect of $\mathrm{HBO}_{2}$ on skin thickness, quality of life, and disease-related disability of the four SS patients who undergone $\mathrm{HBO}_{2}$ therapy due to refractory digital ulcers.

\section{MATERIALS AND METHODS}

In this observational study, 68 SS patients have been followed up in a tertiary care outpatient rheumatology clinic at the time of the study. All patients meet 2013 ACR/ EULAR Classification Criteria for Scleroderma. ${ }^{[16]}$ Forty-four (64.7\%) of them were accepted as limited disease according to skin involvement. Meanwhile, 25 (36.7\%) of the patients had digital ulcers at least once in their disease course. Sixteen $(64.0 \%)$ of them had diffuse and 9 (36.0\%) of them had limited subset of SS.

Four diffuse SS patients from our cohort were treated with $\mathrm{HBO}_{2}$ with the indication of SS-related digital ulcers refractory to the combination therapy of at least three of four medications. These medications were calcium channel blockers, acetylsalicylic acid, iloprost, and bosen$\tan$. The patients were accepted as refractory to medical treatment if their digital ulcers did not respond the medical therapy within 3 months. Then, a rheumatologist and an underwater and hyperbaric medicine (UHM) physician made a joint decision on the necessity of $\mathrm{HBO}_{2}$. None of the patients had contraindication to $\mathrm{HBO}_{2} \cdot{ }^{\left[{ }^{[1]}\right]}$ Durations of $\mathrm{HBO}_{2}$ were decided by the UHM physician depending on clinical parameters. These parameters were number and depth of the digital ulcers and the risk of tissue loss. $\mathrm{HBO}_{2}$ was terminated early in case of therapy-related side effects or complete healing of the ulcers. Furthermore, the patients continued to take their medical treatment for SS and digital ulcers during the study period. All of the patients were literate, and none had pathological finding in the examinations that may influence the questionnaires.

In this study, we evaluated demographic properties (age and gender), disease-related features (duration of Raynaud's phenomenon and digital ulcer, extracutaneous involvement, medications used for SS, and digital ulcer), body mass index, smoking history, comorbidities, antinu- clear antibody (ANA), and anti-Scl-70 status of the patients. We interpreted skin thickness with modified Rodnan skin score (mRSS). ${ }^{[18]}$ The same assessor examined the patient throughout the study. The assessor had 10 years of experience evaluating $\mathrm{mRSS}$. For evaluating intraobserver variability, the assessor interpreted the mRSS of five diffuse SS patients 2 weeks apart. None of these patients were study participants. The intraobserver variability of the assessor has an intraclass correlation coefficient (ICC) of 0.89 (95\% confidence interval, $0.8 \mathrm{I}-0.96)$. We examined mRSS of the patients in both pre- and post- $\mathrm{HBO}_{2}$ periods. Moreover, we interpreted quality of life and disease-related disability with short-form 36 test (SF-36) ${ }^{[19]}$ and health assessment questionnaire $(\mathrm{HAQ}),{ }^{[20]}$ respectively. Both questionnaires were previously validated according to Turkish culture. ${ }^{[2,22]}$ In addition, we evaluated visual analog score (VAS) skin thickness. All these tests were applied to the patients before and after $\mathrm{HBO}_{2}$. Insurance coverage does not permit a second $\mathrm{HBO}_{2}$ session if digital ulcers are also refractory to $\mathrm{HBO}_{2}$. Meanwhile, the other 2 I SS patients in our cohort with digital ulcers responded to the medical therapy.

$\mathrm{HBO}_{2}$ treatment was administered in a multiplace chamber to I 2 patients (Hipertech, Zyron 12, Istanbul, Turkey). Our treatment protocol was $90 \mathrm{~min}$ of oxygen in three 30 min periods with 5 min air breaks at 2.4 atmospheres absolute for routine daily sessions. Patients breathed 100\% oxygen through mask during the therapy.

This study was approved by the Local Research Ethics Committee and carried out in compliance with the Helsinki Declaration. All the patients gave written informed consent.

\section{Statistical analyses}

Statistical analyses were carried out using SPSS Version I7.0 (SPSS Inc., Chicago, Illinois, U.S.). Comparisons of the continuous variables of the patients before and after $\mathrm{HBO}_{2}$ were performed by Wilcoxon test. Moreover, we examined intraobserver variability with the ICC test. $\mathrm{P}>0.05$ was considered as statistically significant.

\section{RESULTS}

All four patients with refractory digital ulcers were female diffuse SS patients. None of the patient had a smoking history, comorbid diseases, and extracutaneous involvement related with SS. During the study period, all patients were on medications for both SS and digital ulcers. Herein, hydroxychloroquine, methotrexate, or a combination of both medications were applied for SS; combinations of calcium channel blockers, acetyl salicylic acid, iloprost, and bosentan were used for digital ulcers. Moreover, none of the patients had taken steroids previously or currently. Patients with medical treatment resistant active digital ulcers underwent $\mathrm{HBO}_{2}$ therapy. Furthermore, serologically, all patients were positive for ANA and anti-Scl-70 (Table I). 


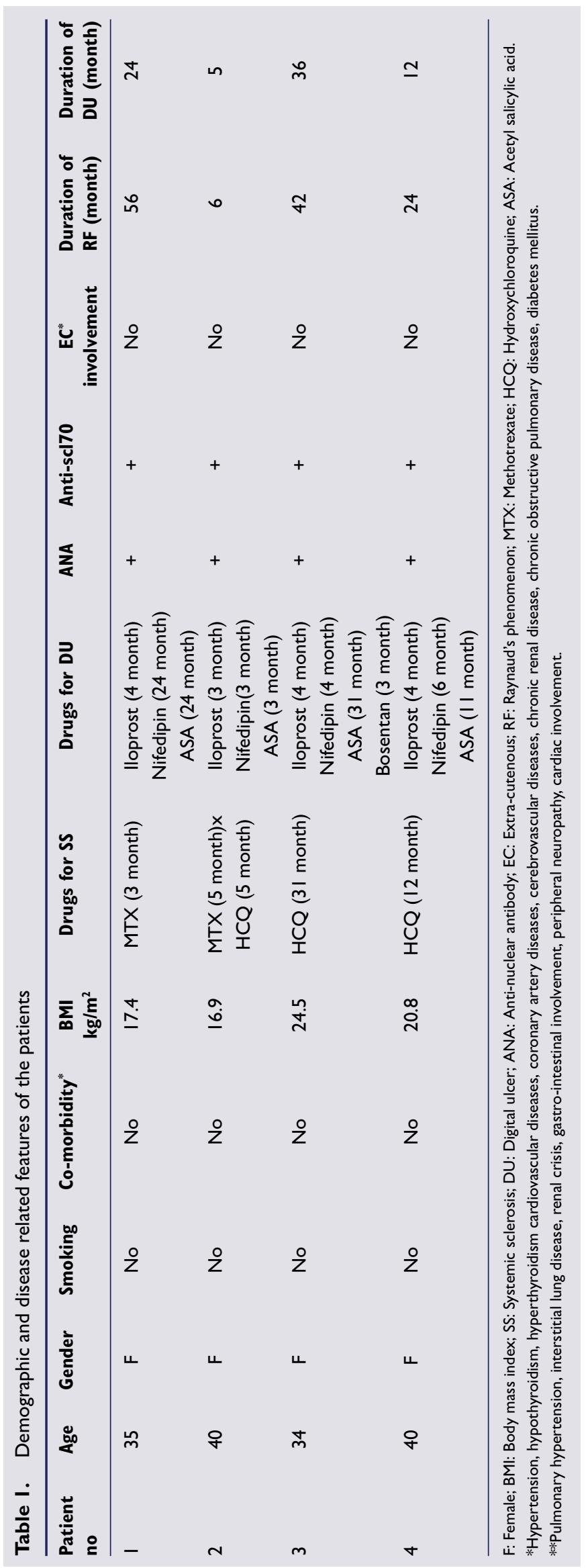

Patient I had four digital ulcers. Three of four ulcers were located in the fingertip and one of them over proximal interphalangeal joints (PIP). Three of them were superficial. Patient 2 had one deep digital ulcer in the fingertip. Patient 3 had eight digital ulcers, all of them located in the fingertips, and three were deep. Patient 4 had three digital ulcers, two located in the fingertips and other over the PIP. All of them were deep. Meanwhile, none of the patient had a local infection related to digital ulcers at the time of the study.

Patient I, Patient 2, and Patient 3 completed the $\mathrm{HBO}_{2}$ therapy within the projected duration without any break. Patient 4 discontinued the $\mathrm{HBO}_{2}$ before projected time due to a private problem. Then, she restarted $\mathrm{HBO}_{2}$ to complete projected duration within 2 weeks' time. At the end of the therapy, digital ulcers in Patient I, Patient 2, and $\mathrm{Pa}$ tient 3 were refractory to $\mathrm{HBO}_{2}$, so these patients did not undergo a second session of $\mathrm{HBO}_{2}$ therapy. In addition, due to the adequate improvement of the digital ulcers in Patient 4, the UHM physician did not consider second $\mathrm{HBO}_{2}$ therapy session for this patient.

Only in Patient 4 the digital ulcers decrease in number with $\mathrm{HBO}_{2}$ therapy. Concurrently, in others, the number of digital ulcers was unchanged.

Even if not statistically significant, after the therapy, the mRSS values of the patients were found to be lower than pre- $\mathrm{HBO}_{2}$ values (Fig. I). Furthermore, VAS skin thickness was improved in three of the four patients. VAS skin thickness was unchanged in Patient 2 (Table 2).

Health assessment questionnaire scores were better in Patient 2 and Patient 4, the same in Patient $I$ and worse in Patient 3. The differences in these parameters were not statistically significant (Table 2).

All SF-36 scales scores of Patient 2 and Patient 4 were improved or unchanged after the therapy. Meanwhile, post-therapy scores of role limitations due to emotional problems and social functioning got worse in Patient I and likewise, all post-therapy SF 36 scales scores except pain deteriorated in $\mathrm{Pa}-$ tient 3 (Table 3).

Patient 3 had the highest number of digital ulcers before treatment. Even though, the mRSS values for Patient 3 were most improved among all four patients, both the HAQ and SF-36 scores of Patient 3 did not get better. Furthermore, Patient I had the second highest number of digital ulcers. HAQ and SF 36 scores did not also improve in this patient. Neither did the scores for Patient 2. The only patient with improved digital ulcers was Patient 4 . In this patient, both quality of life and disease-related disability scores ameliorated after the therapy. 


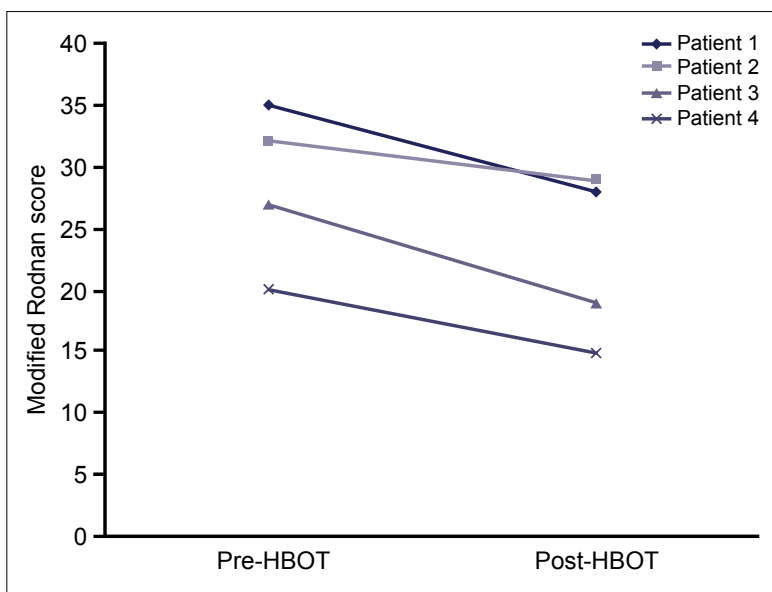

Figure 1. Modified Rodnan scores of the patient before and after hyperbaric oxygen therapy (HBOT: Hyperbaric oxygen therapy).

\section{DISCUSSION}

In our study, we evaluated the effect of $\mathrm{HBO}_{2}$ on skin thickness, quality of life, and disease-related disability. We determined that the mRSS values of the four diffuse SS patients with active digital ulcers had decreased after $\mathrm{HBO}_{2}$ therapy. However, quality of life and disease-related disability parameters did not improve completely in all patients. Moreover, the patient with the highest number of digital ulcers had lower improvement in quality of life and disease-related disability parameters.

There was limited evidence for the treatment of skin thick- ness in SS patients. Methotrexate is one of the options for the treatment of skin thickness in early SS patients. Two randomized controlled trials have demonstrated the effect of methotrexate on skin thickness. In the first study, the effect of methotrexate on mRSS at a dose of $15 \mathrm{mg} /$ week was compared with a placebo. The study duration was 24 weeks. At the end of the study, mRSS values in the methotrexate group improved significantly compared to the placebo group. ${ }^{[23]}$ In a second trial, methotrexate at a dosage of $10 \mathrm{mg} /$ week for 12 months also improved skin thickness significantly in contrast to placebo. ${ }^{[2]}$ Furthermore, cyclophosphamide may have a favorable effect on skin thickness in SS patients. In a study entitled scleroderma lung disease I, cyclophosphamide was shown to be effective for improving skin thickness in compare to placebo. ${ }^{[25]}$ Besides, there were inadequate data for the effectiveness of other medications on skin thickness in SS patients. Recently, autologous hematopoietic stem cell transplantation became a treatment option in SS. It may have positive impact on skin thickness scores. ${ }^{[26]}$ There was no study in literature that evaluated the effect of $\mathrm{HBO}_{2}$ on skin thickness. The results of our study may show the somewhat favorable effect of $\mathrm{HBO}_{2}$ on skin thickness.

$\mathrm{HBO}_{2}$ has both anti-inflammatory and antifibrotic effects that may clarify its favorable effect on skin thickness. TGF- $\beta$ is accepted as one of the key cytokines that relate with fibrotic complications of SS. ${ }^{[27]}$ Moreover, TGF- $\beta$ was also found to be correlated with general disease activity. It was shown that $\mathrm{HBO}_{2}$ may downregulate TGF- $\beta .^{[13]}$ Therefore, diminished TGF- $\beta$ levels connected with the implementation of $\mathrm{HBO}_{2}$ may be one of the reasons for improvement

Table 2. Disease related features before and after hyperbaric oxygen treatment

\begin{tabular}{|c|c|c|c|c|c|c|c|c|c|}
\hline \multicolumn{6}{|c|}{ Pre-HBOT } & \multicolumn{4}{|c|}{ Post-HBOT } \\
\hline $\begin{array}{l}\text { Patient } \\
\text { no }\end{array}$ & $\begin{array}{c}\text { Duration } \\
\text { of HBOT } \\
\text { (day) }\end{array}$ & $\begin{array}{c}\text { Number } \\
\text { of DU }\end{array}$ & $\begin{array}{l}\text { VAS skin } \\
\text { thickness } \\
(0-100)^{+}\end{array}$ & $\begin{array}{c}\text { HAQ } \\
\text { score }^{++}\end{array}$ & $\begin{array}{c}\text { Modified } \\
\text { RS }^{+++}\end{array}$ & $\begin{array}{c}\text { Number } \\
\text { of DU }\end{array}$ & $\begin{array}{l}\text { VAS skin } \\
\text { thickness } \\
(0-100)^{+}\end{array}$ & $\begin{array}{c}\text { HAQ } \\
\text { score }^{++}\end{array}$ & $\begin{array}{c}\text { Modified } \\
\text { RS }^{+++}\end{array}$ \\
\hline I & 36 & 4 & 50 & 0.30 & 35 & 4 & 30 & 0.30 & 28 \\
\hline 2 & 25 & I & 50 & 1.75 & 32 & I & 50 & 1.45 & 29 \\
\hline 3 & 35 & 8 & 50 & 0.30 & 27 & 8 & 40 & 0.60 & 19 \\
\hline 4 & $26 / 25^{*}$ & 3 & 50 & 0.15 & 20 & I & 25 & 0.05 & 15 \\
\hline
\end{tabular}

HBOT: Hyperbaric oxygen treatment; DU: Digital ulcer; VAS: Visual analog scale; HAQ: Health assessment questionnaire; RS: Rodnan score. "Patient 4 has taken HBOT in two different session. ${ }^{+} p=0.10 .{ }^{++} p=0.78 .{ }^{+++} p=0.68$.

Table 3. SF-36 scores of the patients pre and post hyperbaric oxygen treatment

\begin{tabular}{|c|c|c|c|c|c|c|c|c|c|c|c|c|c|c|c|c|}
\hline Patient no & SI & SI* & S2 & $\mathbf{S} 2^{*}$ & S3 & S3* & $\$ 4$ & $S 4^{*}$ & S5 & S5* & S6 & $56^{*}$ & S7 & S7* & S8 & S8* \\
\hline 1 & 55 & 65 & 0 & 0 & 33 & 0 & 15 & 55 & 40 & 68 & 50 & 38 & 100 & 100 & 20 & 20 \\
\hline 2 & 30 & 40 & 0 & 0 & 33 & 100 & 30 & 40 & 64 & 64 & 25 & 38 & 10 & 55 & 40 & 45 \\
\hline 3 & 75 & 60 & 100 & 0 & 33 & 0 & 40 & 25 & 48 & 44 & 50 & 13 & 23 & 33 & 20 & 5 \\
\hline 4 & 70 & 80 & 50 & 50 & 33 & 33 & 45 & 50 & 60 & 68 & 88 & 88 & 78 & 100 & 80 & 80 \\
\hline
\end{tabular}

SF-36 scales: S1: Physical functioning; S2: Role limitations due to physical health; S3: Role limitations due to emotional problems; S4: Energy/fatigue; S5: Emotional well-being; S6: Social functioning; S7: Pain; S8: General health. "Post-HBOT scores was shown with bold letters. SI, $p=0.70 ; S 2, p=0.31 ; S 3, p=I .00 ; S 4, p=0.46$; $S 5, p=0.28 ; S 6, p=0.59 ; S 7, p=0.10 ; S 8, p=0.65$ 
in skin thickness. Furthermore, $\mathrm{HBO}_{2}$ may also ameliorate the hypoxic state in distal extremities, ${ }^{[12]}$ so the risk of hypoxia-related fibrosis may be diminished with $\mathrm{HBO}_{2}$. Pro-inflammatory cytokines, including TNF- $\alpha$, IL-I, IL-6, and interferon gamma, may have a role in fibrosis. The levels of pro-inflammatory cytokines may also decrease with $\mathrm{HBO}_{2} \cdot{ }^{\left[{ }^{[8]}\right.}$ Moreover, the antifibrotic effect of $\mathrm{HBO}_{2}$ is used in post-radiotherapy syndromes and idiopathic oral submucous fibrosis. Furthermore, $\mathrm{HBO}_{2}$ was found successful in post-laminectomy epidural fibrosis through downregulating collagen deposition, IL-6, and TGF- $\beta$ levels. ${ }^{[2]]}$ Therefore, the anti-inflammatory and antifibrotic effects of $\mathrm{HBO}_{2}$ make this therapy a possible treatment option for fibrotic complications of SS.

It was shown in the study by Peytrignet et al. ${ }^{[29]}$ that disability in patients with diffuse SS at baseline was found to be related with current or previous steroid use, current digital ulcers, pulmonary fibrosis, cardiac involvement and muscle involvement, skin thickening, lower levels of hemoglobin, and higher acute phase reactants. Furthermore, in 12 months time, increasing overall skin thickening, decreasing hand function, and increasing fatigue were found to be associated with increasing disability. In the same study, physical components of the quality of life were found to be correlated with current or previous use of corticosteroids, pulmonary fibrosis, cardiac and muscle involvement, and increased skin thickening. The strongest association of the mental components of the quality of life was fatigue. ${ }^{[29]}$ Moreover, Del Rosso et al. ${ }^{[30]}$ showed that systemic organ involvement and skin thickness scores were associated with impaired SF-36 scores. In our study, even though there was a tendency for lower mRSS in all study participants after $\mathrm{HBO}_{2}$, we thought that the number of digital ulcers before therapy would be more decisive for both quality of life and disease-related disability scores before and after therapy. A lower number of digital ulcers before therapy or better response to digital ulcer treatment would be related with better SF-36 and HAQ index scores after $\mathrm{HBO}_{2}$. Therefore, our results might have shown that multiple factors affect both quality of life and disease-related disability in SS patients, as shown in the previous studies. Treatments that address all components of the disease would be required for improvement of quality of life and disease-related disability indices.

Our study has some limitations. First, we evaluated the disease parameters after implementation of just one session of $\mathrm{HBO}_{2}$ therapy. Furthermore, we included a limited number of patients with only digital ulcers. Therefore, the study did not show the effect of $\mathrm{HBO}_{2}$ on SS patients with different systemic involvement. We evaluated study parameters, I time, shortly after the therapy. Therefore, we did not determine the persistency of improvement in skin thickness after $\mathrm{HBO}_{2}$. Finally, we did not utilize the effect of repetitive sessions of $\mathrm{HBO}_{2}$ on disease-related parameters.

$\mathrm{HBO}_{2}$ may have had a favorable effect on skin thickness in the SS patients with active digital ulcers with the im- plementation of just one session. Its anti-inflammatory and antifibrotic properties may be the reason for the improvement in skin scores. Changes in quality of life and disease-related disability indices were limited and inconsistent according to the change in quantity of skin thickness, and this may be related to the multidimensional characteristic of the disease.

Ethics Committee Approval

This study approved by the Kartal Dr. Lütfi Kırdar Training and Research Hospital Clinical Research Ethics Committee (Date: 27.02.2018, Decision No: 20/8/5/4//24/I).

Peer-review

Internally peer-reviewed.

Authorship Contributions

Concept: S.G.S.; Design: M.E.T., S.G.S.; Data: S.G.S.; Analysis: M.E.T.; Writing: M.E.T.; Critical revision: S.G.S.

Conflict of Interest

None declared.

\section{REFERENCES}

1. Goldstein LJ. Hyperbaric oxygen for chronic wounds. Dermatol Ther 2013;26:207-14.

2. Weaver L. Hyperbaric Oxygen Therapy Indications 13th ed. Florida: Best Publishing Company; 2014.

3. Mirasoglu B, Bagli BS, Aktas S. Hyperbaric oxygen therapy for chronic ulcers in systemic sclerosis-case series. Int J Dermatol 2017;56:636-40.

4. Markus YM, Bell MJ, Evans AW. Ischemic scleroderma wounds successfully treated with hyperbaric oxygen therapy. J Rheumatol 2006;33:1694-6.

5. Tjarnstrom J, Wikstrom T, Bagge U, Risberg B, Braide M. Effects of hyperbaric oxygen treatment on neutrophil activation and pulmonary sequestration in intestinal ischemia-reperfusion in rats. Eur Surg Res 1999;31:147-54.

6. Thom SR, Elbuken ME. Oxygen-dependent antagonism of lipid peroxidation. Free Radic Biol Med 1991;10:413-26.

7. Sun Q, Sun Q, Liu Y, Sun X, Tao H. Anti-apoptotic effect of hyperbaric oxygen preconditioning on a rat model of myocardial infarction. J Surg Res 2011;171:41-6.

8. Inamoto Y, Okuno F, Saito K, Tanaka Y, Watanabe K, Morimoto I, et al. Effect of hyperbaric oxygenation on macrophage function in mice. Biochem Biophys Res Commun 1991;179:886-91.

9. Buras JA, Holt D, Orlow D, Belikoff B, Pavlides S, Reenstra WR. Hyperbaric oxygen protects from sepsis mortality via an interleukin-10-dependent mechanism. Crit Care Med 2006;34:2624-9.

10. Bennett M, Heard R. Hyperbaric oxygen therapy for multiple sclerosis. Cochrane Database Syst Rev 2004;1:CD003057.

11. Rossignol DA. Hyperbaric oxygen treatment for inflammatory bowel disease: A systematic review and analysis. Med gas Res 2012;2:6.

12. Utsunomiya H, Tilakaratne WM, Oshiro K, Maruyama S, Suzuki M, Ida-Yonemochi $\mathrm{H}$, et al. Extracellular matrix remodeling in oral submucous fibrosis: Its stage-specific modes revealed by immunohistochemistry and in situ hybridization. J Oral Pathol Med 2005;34:498-507.

13. Hopf HW, Gibson JJ, Angeles AP, Constant JS, Feng JJ, Rollins MD, et al. Hyperoxia and angiogenesis. Wound Repair Regen 2005;13:558-64. 
14. Ye X, Zhang J, Lu R, Zhou G. HBO: A possible supplementary therapy for oral potentially malignant disorders. Med Hypotheses 2014;83:131-6.

15. Denton CP, Khanna D. Systemic sclerosis. Lancet 2017;390:168599.

16. van den Hoogen F, Khanna D, Fransen J, Johnson SR, Baron M, Tyndall A, et al. 2013 classification criteria for systemic sclerosis: An American college of rheumatology/European league against rheumatism collaborative initiative. Arthritis Rheum 2013;65:2737-47.

17. Hoesen KB. Wilderness Medicine. 6th ed. United States: Hyperbaric Medicine, Mosby; 2011.

18. Khanna D, Furst DE, Clements PJ, Allanore Y, Baron M, Czirjak L, et al. Standardization of the modified Rodnan skin score for use in clinical trials of systemic sclerosis. J Scleroderma Relat Disord 2017;2:11-8.

19. Ware JE Jr., Sherbourne CD. The MOS 36-item short-form health survey (SF-36). I. Conceptual framework and item selection. Med Care 1992;30:473-83.

20. Bruce B, Fries JF. The stanford health assessment questionnaire: A review of its history, issues, progress, and documentation. J Rheumatol 2003;30:167-78.

21. Kucukdeveci AA, Sahin H, Ataman S, Griffiths B, Tennant A. Issues in cross-cultural validity: Example from the adaptation, reliability, and validity testing of a Turkish version of the stanford health assessment questionnaire. Arthritis Rheum 2004;51:14-9.

22. Celik D, Coban O. Short form health survey version-2.0 Turkish (SF$36 v 2$ ) is an efficient outcome parameter in musculoskeletal research. Acta Orthop Traumatol Turc 2016;50:558-61.
23. van den Hoogen FH, Boerbooms AM, Swaak AJ, Rasker JJ, van Lier HJ, van de Putte LB. Comparison of methotrexate with placebo in the treatment of systemic sclerosis: A 24 week randomized doubleblind trial, followed by a 24 week observational trial. Br J Rheumatol 1996;35:364-72.

24. Pope JE, Bellamy N, Seibold JR, Baron M, Ellman M, Carette S, et al. A randomized, controlled trial of methotrexate versus placebo in early diffuse scleroderma. Arthritis Rheum 2001;44:1351-8.

25. Tashkin DP, Elashoff R, Clements PJ, Goldin J, Roth MD, Furst DE, et al. Cyclophosphamide versus placebo in scleroderma lung disease. N Engl J Med 2006;354:2655-66.

26. Shouval R, Furie N, Raanani P, Nagler A, Gafter-Gvili A. Autologous hematopoietic stem cell transplantation for systemic sclerosis: A systematic review and meta-analysis. Biol Blood Marrow Transplant 2018;24:937-44.

27. Lafyatis R. Transforming growth factor beta--at the centre of systemic sclerosis. Nat Rev Rheumatol 2014;10:706-19.

28. Lv P, Zhao J, Su W, Liang X, Zhang K. An experimental novel study: Hyperbaric oxygen treatment on reduction of epidural fibrosis via down-regulation of collagen deposition, IL-6, and TGF-beta1. Eur J Orthop Surg Traumatol 2015;25 Suppl 1:S53-8.

29. Peytrignet S, Denton CP, Lunt M, Hesselstrand R, Mouthon L, Silman A, et al. Disability, fatigue, pain and their associates in early diffuse cutaneous systemic sclerosis: The European scleroderma observational study. Rheumatology (Oxford) 2018;57:370-81.

30. del Rosso A, Boldrini M, D’Agostino D, Placidi GP, Scarpato A, Pignone A, et al. Health-related quality of life in systemic sclerosis as measured by the short form 36: Relationship with clinical and biologic markers. Arthritis Rheum 2004;51:475-81.

\section{Hiperbarik Oksijen Tedavisinin Sistemik Skleroza Bağlı Deri Kalınlığına Olumlu Etkisi Olabilir: Dört Hasta ile Deneyim}

Amaç: Hiperbarik oksijen tedavisinin $\left(\mathrm{HBO}_{2}\right)$ antienflamatuvar ve antifibrotik etkisi bulunmaktadır. Sistemik sklerozda (SS) dijital ülserler gibi kronik yara tedavisinde etkisi olduğu gösterilmiştir. $\mathrm{HBO}_{2}$ tedavisinin, ek olarak SS'a bağlı fibrotik değişikliklere de etkisi olabileceği düşünülmektedir. Bu çalışmada, medikal tedaviye dirençli dijital ülseri bulunan hastalarda, $\mathrm{HBO}_{2}$ tedavisinin SS bağlı deri kalınlığına olan etkisi araştırılmıştır.

Gereç ve Yöntem: Bu çalışma gözlemsel ve retrospektif bir çalışmadır. Altmış sekiz hastadan olan SS kohortumuzdaki hastaların 25 'inde dijital ülser tespit edilmiştir. Bu hastaların dördünde medikal tedaviye dirençli dijital ülser gözlenmiştir. Öncelikle hastalara medikal olarak kalsiyum kanal blokerleri, asetil salisilik asit, iloprost ve bosentan tedavilerinden en az üçü uygulanmıştır. Bu tedaviye dirençli hastalar, romatolog ve sualtı ve hiperbarik uzmanları tarafından $\mathrm{HBO}_{2}$ açısından değerlendirilmiştir. Takiben uygun hastalara $\mathrm{HBO}_{2}$ tedavisi verilmiştir. Hastaların tedavi öncesi ve sonrası modifiye Rodnan skorları (mRSS), sağlık değerlendirme anketi hastalığa bağlı kısıtılık ve kısa form-36 testi ile hayat kalitesi ölçülmüştür. Ayrıca hastaların deri kalınlığına yönelik görsel analog skalası değerlendirilmiştir.

Bulgular: mRss skorunda tüm hastalarda tedavi sonrası düzelme gözlenmiştir. Ancak, sadece bir hastanın dijital ülserinde anlamlı düzelme gözlenmiştir. Ayrıca, hastalığa bağlı kısıtlıık ve hayat kalitesi değerlendirmelerinde anlamlı değişim tespit edilmemiştir.

Sonuç: $\mathrm{HBO}_{2}$ tedavisi, SS bağlı deri kalınlı̆ına antienflamatuvar ve antifibrotik etkileri ile olumlu değişim sağlayabilir. Hayat kalitesi ve hastalığa bağıı kısıtlııkta düzelme için hastalıkla ilgili tüm alanlara yönelik tedaviler gerekmektedir.

Anahtar Sözcükler: Deri kalınlığı; hastalığa bağlı kıııtııık; hayat kalitesi; hiperbarik oksijen tedavisi; sistemik skleroz. 